\title{
War-Induced Displacement: Hard Choices in Land Governance
}

\author{
Gemma van der Haar ${ }^{1, *}$ and Mathijs van Leeuwen ${ }^{2}$ \\ 1 Sociology of Development and Change group, Wageningen University, 6700 EW Wageningen, \\ The Netherlands \\ 2 Centre for International Conflict Analysis and Management, Institute for Management Research, \\ Radboud University Nijmegen, 6500 HK Nijmegen, The Netherlands; m.vanleeuwen@fm.ru.nl \\ * Correspondence: Gemma.vanderhaar@wur.nl; Tel.: +31-317-483-514
}

Received: 22 April 2019; Accepted: 23 May 2019; Published: 1 June 2019

\begin{abstract}
Civil war and violence often force large numbers of people to leave their lands. Multiple waves of displacement and (partial) return generate complex overlapping claims that are not easily solved. As people return to their regions of origin-sometimes after decades-they tend to find their land occupied by other settlers, some of whom hold legal entitlements. In the places of arrival, displaced people affect other people's access as they seek to turn their temporary entitlements into more definite claims. The overlapping claims related to displacement pose serious dilemmas to land governance, which existing land laws and land governance institutions are not well-equipped to deal with. This paper outlines the main challenges for land governance as a first step to move the debate forward. The paper summarises the key challenges around three tensions: first, between short term conflict resolution and structural solutions; second, between state and customary/community-based governance; and finally, between principles (such as the right to return or restitution) and acknowledgement of the new situation.
\end{abstract}

Keywords: land governance; forced displacement; conflict; violence

\section{Introduction}

Civil war and violence often force large numbers of people to leave their lands. The latest figures of UNHCR (the United Nations High Commissioner for Refugees) talk of 68.5 million forcibly displaced people worldwide, of which 40 million are internally displaced and the remainder are refugees [1]. Such war-related displacement is not only a matter of humanitarian concern but also, as we will argue, a land governance issue. In this paper, we outline what we understand to be the main challenges for land governance deriving from displacement induced by war and violence. We argue that displacement leads to competing claims on land that pose serious dilemmas, which existing land laws and land governance institutions are generally not well-equipped to deal with.

This paper aims to contribute to more effective, just, and sustainable solutions to land governance, for what are extremely complex situations. In many war-affected settings, there are no easy solutions, and land problems may drag on for years or even decades, hampering the recovery of livelihoods, causing distress and, in some cases, instability. Governments and non-governmental agencies struggle to address these issues. We hope that the discussion offered here can help to better understand the problems, and to chart ways forward in responsible and effective land governance in settings affected by displacement and return.

In this paper, we first show that displacement related land problems are very complex to start with (Section 2). We then argue that matters are further complicated by the fact that actors that could address these issues effectively are often lacking, as the instruments they have to do so are very limited, and the 
conditions under which they have to do so are highly challenging and not always conducive to fair outcomes (Section 3). Next, we identify three key dilemmas that land governance interventions need to engage with to develop ways forward (Section 4) and end by suggesting some possible directions (Section 5).

This paper draws on insights generated in a series of research projects conducted by the authors, often in collaboration with others, over the past years in various parts of Africa, especially the Great Lakes region. In the project 'Grounding Land Governance' (2011-2016), we explored how land governance evolved in conflict-affected Uganda, Burundi, and South Sudan. We studied, in particular, how decentralized forms of land governance impacted the legitimacy and authority of local land tenure institutions, influenced relations of governance, and affected the resolution of land conflicts. This project included $3 \mathrm{PhD}$ trajectories and one post-doc research project. The applied research project, 'Looking through the Lens of Land' (2014-2016), looked into land-related justice concerns as experienced by local people in conflict-affected settings in the eastern Democratic Republic of Congo (DRC) and South Sudan and how state and non-state authorities and development organizations responded to these. Issues related to displacement and return featured in both research projects as particularly complex and challenging to local populations as well as state agents and intervening agencies. Both projects included knowledge sharing workshops with local and international stakeholders and the collaborative formulation of policy recommendations. The key challenges featured in this paper emerged from discussions in these workshops. Next to these two larger projects, various smaller projects and consultancies on humanitarian assistance, Local Peace Committees, and land governance reform in Burundi and eastern DRC provided further insights.

The term land governance has come up next to already existing terms such as 'land rights' and 'land administration,' which it encompasses. Land governance generally refers to the apparatus, norms, legal frameworks, and decision making procedures, developed by the state, or other actors to regulate land access, management, and control, as in the following definition of the FAO (Food and Agriculture Organization of the United Nations): "Land governance concerns the rules, processes and structures through which decisions are made about access to land and its use, the manner in which those decisions are implemented and enforced, and the way in which competing interests in land are managed" [2] (p. 9). When we use the term land governance in this paper it is to talk about the ambitions, practices, interventions, and outcomes in the regulation of land access and land claims, of both governmental and non-governmental bodies, at a local, national, or international level.

\section{War-Induced Displacement as Cause for Competing Claims to Land}

Conflict and violence tend to generate multiple waves of displacement and (partial) return that affect people's land claims in both the regions of origin and the regions where they (re-)settle. This section outlines these dynamics, discussing the types of overlapping claims that occur.

\subsection{The Nature of Competing Claims in Places of Departure and Return}

War-related displacement may take many forms, and so its effects on land access may be expected to vary. Temporary displacement to escape from violence, to the relative safety of nearby forests, or to relatives, may affect people's access to fields, but need not compromise their land claims in the longer term. These types of displacement tend to remain unregistered however and, so far, have not attracted researchers' attention. When people abandon their places of residence for a longer period and move over larger distances (sometimes crossing national boundaries), the risk that they lose their rights to fields and houses becomes much higher. In some cases, people never return to their regions of origin or take decades to do so (on Burundi, [3,4]). Over such a timespan, they may find it very hard to reclaim their original rights. Often, they will find their land occupied by other settlers, some of whom may by then hold (some form of) legal entitlement. Regions of departure for some may have become the regions of arrival for others on the move, whether fleeing for violence or migrating in search of 
better economic opportunities. In the absence of the original owners, neighbours or newcomers can appropriate the land, invest in it, or sell it, creating a situation that is not easily reversed [5-9].

In other cases, lands vacated by people fleeing insecurity are claimed for large scale plantations, mining, logging, or nature conservation. Some of these lands are acquired by powerful military and political actors, often with state approval or support. There is abundant literature on this for conflict-affected settings worldwide, including the cases of Colombia [10], Burma [11], Burundi [12], Northern Uganda [13], eastern DRC [14,15], and South Sudan [16]. The literature suggests that there is a grey area between entrepreneurial actors making smart use of the opportunities offered by 'empty' land and the deliberate and violent 'emptying' of land to open it up for resource extraction, agribusiness, or, in the case of Colombia, production of illicit crops. Like small scale claims by other smallholders, these larger scale claims are often hard to reverse in the post-peace agreement period.

Like displacement, return may also take various shapes. Sometimes return is piecemeal, individual, and largely self-organised. People start to explore what is the situation and (part of) the family may decide to return. This may result in the sale of land of relatives that have not yet returned, or the distribution of family land, which then later results in disputes [17]. In other settings, return may be centrally orchestrated. In Burundi, we found that political pressure was put on refugees to return to their areas of origin in the Makamba region after having lived in Tanzania for more than thirty years [18].

It will be clear from the above discussion that returnees may have a hard time reclaiming their original rights. They will need to oppose the claims on their fields, grazing lands or housing plots, some of which are backed by the law and/or powerful actors. Their efforts are hampered by practical difficulties to produce any form of proof on these earlier entitlements. This is the case especially in situations of customary land tenure, which relies on land marks (often disappeared) or on the memory of elders or customary authorities (often dead or displaced; see [19]). Land records may offer little help to sort out claims, as records may have been destroyed as a side effect of war, deliberately destroyed, or very limited to start with. When evidence is not available or inconclusive, it becomes nearly impossible to clarify who held what rights.

\subsection{The Nature of Competing Claims in Places of Arrival}

Overlapping claims occur not only in regions of departure but also in regions of arrival, where displaced people settle for a longer or shorter term. Though evidence is not conclusive on this topic, we may hypothesize that more complex problems occur when the numbers are higher and when temporary settlement becomes more permanent. Displaced people may find refuge in unoccupied houses or on commons at the outskirts of villages. They may do so through negotiations with local authorities, through deals with private owners, or as assigned by higher level authorities (authors' personal observations from Burundi, DRC, southern Mexico, Lebanon). When new-coming families stay longer, they seek to turn their temporary entitlements into more definite claims. Newcomers' presence affects local life, but whether this turns problematic may be expected to depend on the scale of in-migration, but also on the degree of affinity (cultural, political) between the different groups of population.

This is not only, or primarily, a rural issue. Particular issues emerge in urban centres that witness intense demographic change. In DRC, for example, steep urban growth was registered as people turned to cities as relatively safe havens. The city of Bukavu grew exponentially due to two decades of conflict, implying higher pressures on urban space and services [20]. Mining sites in remote regions in eastern DRC boomed and became 'mining towns' [21]. Research by our own team and others has documented how in Yei town, in South Sudan, displacement led to a drastic recomposition of the population, as most of the original inhabitants fled and their places were taken by those displaced from other war-affected regions and by soldiers from the Sudan People's Liberation Army (SPLA) and their families. As earlier residents returned after the 2011 peace agreement, this recomposition lead to tensions $[7,8,22,23]$. 
Attention for the situation in settings of arrival is growing, as it is being acknowledged that only a small portion of displaced people are hosted in formal Internally Displaced Person (IDP) or refugee camps $[24,25]$. Many end up in regional urban centres. Camps, however, do generate land claims of their own and affect land access and pressures on natural resources in the immediate vicinity of the camp and beyond $[18,26]$.

\section{Factors that Complicate Land Governance in Conflict-Affected Settings}

Competing claims related to displacement usually start to be addressed in the context of post-conflict policies, when they are seen as a risk for peace-building and development. However, a number of factors in post-war settings complicate finding effective solutions: the lack of land governance actors with sufficient capacity and credibility, the lack of instruments that are well-tailored to the situation on the ground, and the conditions in war-to-peace transitions that are conducive to (ethno-) political competition and land grabbing.

Our interest in this section is to outline how factors related to the land governance system itself and the wider political force-field in which it operates, add additional complexity to the problems arising from displacement related land claims. As mentioned, a first obstacle to adequate responses to completing land claims in conflict-affected settings is the lack of evidence on who held what previously. We argue however that the problem is more fundamental and includes governance actors themselves and the conditions under which they operate. We need to understand better the interconnections between shifts in occupational patterns due to displacement, shifts in land control following ethno-political changes (related, for example, to ethnic cleansing), and changes in governance [27,28].

\subsection{Land Governance Actors Lack Capacity and/or Legitimacy}

As Jon Unruh has so aptly noted [27], protracted conflict tends to affect the very actors that could potentially help provide solutions to land conflicts. This includes both state and non-state actors. Our concern is that, in the aftermath of war, when a start might be made with solving land issues, we are faced with a lack of authorities who have both the commitment and the means to craft solutions in contexts marked by division and uncertainty. We claim that this is more than just a technical capacity issue, such as the reduction of governmental expertise on land issues, the lack of funds, or the absence of land registers; it is also a problem of authority and legitimacy.

Violent conflict may undermine state capacity and legitimacy, often deepening earlier problems [27]. This process tends to be highly uneven, however. Whereas a state's presence and legitimacy erode in some regions, those factors may be harnessed in other regions: the state may lose control in regions where its competitors are strong and may strengthen its grip on more 'loyal' regions [27]. In post-peace agreement settings, such an uneven presence may persist, or the state may try to reverse it, imposing its rule in former rebellious territory. Where its social legitimacy is low, the state is unlikely to be able to play a constructive role on finding solutions for competing claims and risks, thereby engendering further division. State action may turn punitive, and annul entitlements granted by insurgent actors or acquired by people at the margins of state control.

Other forms of public authority may not be able to fill the gap. On the one hand, customary systems of authority, the fall-back option in much of Africa, tend to be severely affected by conflict and displacement. Customary leaders, such as chiefs or elders, may simply no longer be there; they may have been targets during the war, or may not have returned from displacement. As leaders are separated from their constituencies or settled outside of their regions of origin, their authority may no longer be recognised, $[15,27,29]$. On the other hand, there are examples of war-based, insurgent authorities that engage in land governance in areas under their control. The legitimacy of insurgent authorities is socially and spatially circumscribed, however, and in war-to-peace transitions, they tend to be questioned or actively opposed [30,31]. 
Yei River County, in the newly independent South Sudan, presents an example of the complexities involved. Due to war-time displacement and migration, communities in Yei represent an amalgam of different groups claiming the right to land and to settle in the city, each with different political allegiances and their own leadership. Amongst them, there is no agreement on overarching leadership, property norms, or procedures for dispute settlement [32]. This leads to continuous tensions and competition amongst customary authorities and between customary authorities and the state, often at the expense of customary authority [33]. Along similar lines, research by our team and others found that life in IDP camps in northern Uganda led to a loss of authority of male family heads but also spurred the commoditization of land [34,35].

After recognising the problems in domestic land governance capacity in conflict-affected regions, international donors step in. These donors engage with land issues as part of broader post-conflict peace building and development policies, especially in countries where land conflict is seen as a driver of violence [36]. On the one hand, peace-building policies often include land law reform, to be effectuated by the state with support from international donors. On the other hand, as we found in our research in the Great Lakes region, localised land certification and conflict mediation schemes are set up and executed by NGOs [37]. These efforts are important in light of the urgent needs on the ground but cannot, however (as we will suggest further below), serve as a substitute for a functioning state.

\subsection{The Lack of Legal Yardsticks and Suitable Frameworks}

Forced displacement not only undermines authority but also defies common legal frameworks and established societal norms about property. We suggest that land governance instruments at the state level as well as most customary norms are not tailored to these out-of-the-ordinary situations. As customary systems are undermined by protracted conflict, as indicated in the previous section, customary property norms may also lose their earlier legitimacy and suitability. War-induced displacement feeds into this, as different population groups who come to share a geographical space each bring their own norms and authorities, as noted above for the case of Yei in South Sudan. Where some of these may oppose the state, others may turn to it for support. Furthermore, the acceptance of customary norms in (fast growing) urban settings is not self-evident.

We suggest that land governance frameworks globally are not well-suited to the challenges of intense shifts such as those that happen due to conflict. Land laws designed for a situation of normality do not have clear answers to the exceptional situations that arise around displacement and return, in which different legal principles compete. However, the framework designed especially for displacement issues, known as "the Pinheiro Principles" on property restitution, which grants displaced people the right to reclaim their properties or receive compensation, offers only partial answers. It is clear that insisting on the principle of restitution, especially after an absence has been long lasting, would affect the entitlements of a range of more recent claimants and come at a high social cost. In Burundi, we found that the right to restitution of returnees clashed with the state-backed titles held by some of the later owners $[17,18]$.

An open question is what "Fit for Purpose" technologies for recording land rights might mean in displacement contexts. Our preliminary suggestion is that these can be useful as an instrument for recording property, but do not seem well-suited to address situations of division, where contestation is strong and there is no basic agreement on entitlement, nor on the norms that should prevail, nor on who are legitimate authorities. Though frameworks and technologies such as these may hold promise for the future, their application and impact should be followed closely across a number of settings.

\subsection{Unfavourable Conditions for Land Governance}

War-to-peace transitions feature a number of factors that complicate the deployment of land governance towards constructive solutions. These factors are the continuation of ethno-political strife, often implicating the state; the existence of an 'open moment' for land grabbing; and competing demands for stability and generation of revenue to kick-start development. 
Wartime political strife tends to continue in other guises after war. Competing claims on the ground reflect these broader tensions and have political connotations far beyond individual concerns with livelihood security. This is clear in South Sudan, for example, where soldiers from the liberation movement SPLA, many of whom were Dinka from other parts of South Sudan, defended their occupation of lands and houses of people who had fled, arguing that they had 'liberated' these lands, spending their blood, while original residents had 'forfeited' their rights by fleeing [38,39]. As displaced people returned, however, seeking to recover their rights, they did not accept that these soldiers were victims but resented them as the vanguard of a Dinka agenda to (re-) occupy the southern part of South Sudan [22].

Interventions to address completing claims are also seen in relation to such broader, politicised frames of reference. Political intentions are read into what seem to be technical land governance interventions, making solutions highly sensitive. In Burundi, we found that the involvement of the national land commission (CNTB) on behalf of returnees from Tanzania got linked to ethno-political tensions and claims of citizenship and (ethnic) belonging [18].

Another important factor is the fact that war-to peace transitions present a conducive environment for land grabbing [40]. Predatory wartime behaviour continues, or even intensifies, as people use the window of opportunity that is created as the land governance system is in disarray and new laws and stricter procedures for land transfer are not yet in place. This may deepen the dispossession derived from displacement. As people are not on the ground to stake their claims, and the state does not protect their rights, their lands get claimed by international or domestic actors $[14,39]$. In various settings in our research, we observed how widows, divorced women, and orphans notably fell victim to irregular appropriation of land after conflict.

A final, closely connected factor relates to the pressures that war-affected countries may experience to generate revenues for recovery. Investments in mineral extraction or agribusiness offer to bring in much needed public (and private) revenue in the name of development. Similarly, foreign aid often includes a liberalisation package [41,42] that presses governments to open up their land and natural resource base to the market and promote private sector development. Both of these dynamics risk compromising the land access of local populations and, in particular, that of the displaced.

\section{Key Dilemmas in Land Governance}

One of the most complex issues around displacement-related land problems is that there may be no evidently just or fair solution to the multiple, overlapping entitlements and competing claims that arise. In the cases we studied, different groups of people had good reasons to claim something as theirs. We also found that there is often no undisputed legal principle that can serve as a yardstick to solve this problem.

During the interviews and workshops that were conducted as part of the research of our team in the Great Lakes region, this challenging situation and possible solutions were discussed at length. On the basis of these discussions, we identify three core dilemmas for land governance interventions in settings affected by conflict-induced displacement and return, which we discuss in this section. We hope that outlining the dilemmas serves as a first step towards addressing them.

What was clear from our discussions was that answers are needed to resolve tensions in the short term without, however, compromising social justice and the development of a robust system of land governance in the longer term. Land governance cannot wait for state-building to be completed or for local societies to have fully recovered from war, but neither should one come to hasty solutions that undermine structural answers in the future. Outside assistance may be needed, but the answer cannot rely on international intervention only or primarily. Ways forward would need to work towards solutions for concrete problems on the ground in ways that feed into fair, equitable, and 'future-proof' systems of land governance. 


\subsection{Promoting Short Term Conflict Resolution Without Undermining Structural Solutions}

One of the most difficult challenges in land governance is to work on short term solutions for immediate problems while at the same time building more structural solutions that are future-proof. The fear for a re-ignition of conflict [43] often promotes an approach of defusing local tensions and grievances around land. In DRC, we found multiple programmes of non-governmental agencies working on local level conflict resolution around land and certification schemes [37]. We see two main problems with these, which have broader relevance.

In the first place, it is not clear how such short term, localised interventions-especially when developed by a range of international NGOs-will feed into the building of an effective and legitimate framework for land governance. A solid, workable land governance structure takes time to build, and isolated investments may not do the job. This was an often-voiced concern in the DRC. It was unclear how specific interventions (e.g., for recording customary claims to land) aligned with each other and the formal legal system. There was a concern, especially on the side of state representatives, that this would compromise future harmonisation and make arrangements unsustainable. A related concern was that it was not clear how such localised interventions would contribute to building up institutions for land governance with a wider reach. One explanation for the lack of alignment with state frameworks was the widespread distrust of the Congolese state amongst interveners. Though their concerns about the state may be partly justified, their choice does compromise the ambition of arriving at an effective and legitimate land governance framework and reduce chances that diverse interventions eventually add up to more than the sum of their parts.

Second, short-term conflict resolution may in essence be a containment approach that prioritises defusing conflict in the short term over considerations of justice in the long run. This approach avoids asking political questions about legitimate ownership and fair land distribution. It further risks institutionalising wartime (or even older) appropriations where redressal of these issues should also be considered. We found a striking example of this in our work in the case of Kitchanga, in eastern DRC, where an international organisation mediated a compromise between former labourers of a plantation and the current concession holder. The negotiated outcome was that some of the former labourers got access to the concession, whilst giving up on the larger parts of their claims, including outstanding payments and resistance against plantation agriculture. This brought temporary peace. However, during the process, indications arose that the current owner might not be the lawful owner and did not use the concession according to its destination. Those could have been reasons for the state to annul the concession and grant the claims of the former labourers. However, while demanding implementation of the law might have been more beneficial for the former labourers, the organisation opted to broker a give-a-bit, take-a-bit solution for political reasons. In their view, insisting on the law would have incited strong, possibly violent actions from the side of the concession owners who are part of a very powerful politico-military elite. While interveners believed they had achieved a good compromise, people affected had the feeling that their concerns were not really solved [44].

We acknowledge that redistributive actions carry their own risks of further upheaval. On the one hand, the perceived urgency to act may result in rather drastic reforms, which generate widespread land tenure insecurity, as in Rwanda, where land access was reshuffled to promote agricultural development $[45,46]$. On the other hand, there might be hesitance to reform not to affront elites, as we observed in Burundi in the period before president Nkurunziza took office. Interventions, therefore, need to manoeuvre between the need to take agrarian injustices seriously [47], and the room to enforce reforms without causing severe backlashes on groups of claimants. They also need to avoid the risk that reforms focus too much on displacement related, war-generated disputes, at the cost of attention for more structural forms of tenure insecurity (see e.g., the case of Burundi [48]).

\subsection{Reconciling State Building with Strengthening Customary and Community-Based Institutions}

Land governance reforms since the 1990s have increasingly acknowledged the roles of non-state and so-called 'customary' institutions in securing tenure, at least on paper $[49,50]$. At the same time, 
states continue to be recognised as key actors in post-conflict transitions, better placed than others to provide a crucial space for political representation and accountability [51], and to uphold the rule of law. On its turn, land governance is a critical space where state formation takes shape [31,52].

How to move along this state-non-state axis in land governance is challenging. Many interveners consider it a priority to (re-)establish the state's capacity to provide security, development, and political representation. Yet, in many conflict-affected settings, states have lost legitimacy due to their involvement in violence against their own citizens or irregular land acquisitions. For instance, many people in the Acholi region in northern Uganda, believe the war and forced displacement were orchestrated by the government to appropriate their land [53]. Likewise, customary institutions may be a source of protection or insecurity. In some cases, they are known to help women secure access to land, or protect the land for their children [54], but in other instances, they may discriminate against women and youth, marginalize non-indigenous community members and non-residential user groups, such as pastoralists [55], or mainly benefit local elites [56]. A key question is also to what extent they may uphold land claims of migrants and displaced.

In many settings, state and non-state institutions compete for legitimacy. Land governance reforms in conflict-affected settings may feed into such institutional competition, or lead to the creation of new, parallel institutions, while land governing responsibilities of different institutions are not spelled out, and newly introduced norms may remain ambiguous or contested. This competition leads to confusion among contestants about which institutions are in charge, and ongoing appeals on decisions to be taken. Moreover, competition creates space for political entrepreneurs, with unpredictable outcomes on tenure security [57]. Interventions that feature a reorganization of administrative responsibilities need to be cautious when this reorganization implies the creation of parallel institutions; interventions should also promote a local understanding of new divisions of roles and responsibilities.

Indeed, decentralised forms of land administration, as introduced in various conflict-affected settings, sometimes enhance local tenure security and reduce land-related conflicts. However, in many of the localities where we conducted research, decentralized land administration also fed into power struggles between state and non-state authorities at the local level, and effectively enhanced the power of the state over local land. In South Sudan, while chiefs (re)gained a role in decentralized government, other forms of customary authority were effectively side-lined. Moreover, the strengthening of the (state-affiliated) chiefs enhanced opportunities for displaced people and migrants to make claims to land at the expense of the original right holders [58]. Interventions in land governance cannot do without a vision on the development of local public authority, notably on what type of institutions to promote. In this way, there should be a focus on promoting good land governance practices for state and non-state institutions, rather than on strengthening state institutions by default.

\subsection{Striking a Balance between Restoring Pre-War Rights and Acknowledgement of New Normalities}

We suggest that developing sustainable solutions involves balancing legal principles with considerations of social justice and legitimacy. Given the complexity of displacement-related land problems, doing justice to one claim often means to deny another, further victimising people who have also suffered loss of entitlements. A strict application of the principle of restitution of pre-war possession may lead to socially undesirable outcomes. The case of Makamba in Burundi serves to illustrate this. Here, we found state restitution policies to favour Hutu returnees from Tanzania (who had fled in 1972) at the expense of the Tutsi occupants of their former properties. The national land commission (CNTB) posited the former as lawful 'war victims' and legitimate claimants, and framed the latter as illegitimate settlers and encroachers. In their turn, the Tutsi were displaced and their political leaders identified the displaced Hutu as accomplices in the violence against the Tutsi people during past conflicts, while they viewed themselves as victims of a (hidden) political agenda of the current government to marginalise them and to dispossess them of their legitimate rights to land and safety. As local divisions hardened, the room for negotiated solutions diminished and earlier 
land sharing arrangements were revised to more exclusionary solutions favouring one party over the other [18].

A return to pre-war normalities is, in settings affected by long-term violent conflict, often an illusion. Restoring land rights to the pre-war situation without considering what else has changed, might do more harm than good. Rather than a principle of restitution to original owners, a principle of social justice, of fairness to all war victims, might be a more pragmatic and, in the end, more constructive starting point. We suggest that the way forward might be found in a careful and tailor-made approach to recovering pre-war entitlements, which also takes into consideration more recent rights and alternative solutions such as compensation. This might not only fit individuals' new circumstances better, it would also create more room for negotiated outcomes that are experienced as fair and 'acceptable-enough' across different groups of claimants, even where it means people could not get all their claims honoured. Local legitimacy is the key here, and not imposed solutions, such as the land sharing arrangements that were observed in Rwanda [58].

A return to pre-war normalities is difficult where the ethnic make-up has changed drastically due to the war, and people do not feel safe to return (for an example from Bosnia, see [59]). Further, those who found a safe haven in an urban setting might not want to give up the life they have built up. In urban settings, it is often difficult to clearly distinguish forced displacement and migration. Some people seek refuge from violence, while others are attracted by the economic opportunities provided in urban environments, and often the two motives intertwine. Either group may prefer to stay for the better chances for developing livelihoods [60]. This phenomenon means that we require land governance instruments to govern the increased pressures on urban spaces, as net receivers of displaced people, and ways to determine the entitlements of newcomers.

Taking into consideration the existing situation does entail a risk of institutionalising injustices created during the war. Our argument is not that land governance should give up on righting the wrongs of war. Rather, we suggest that land governance needs to make the necessary moral judgements on both old and new claims. Legitimacy and social justice are key here. Land governance solutions should detect illegitimate wartime land acquisition and not honour these with peace time institutionalisation and regularisation. Any larger scale war time land transfer should be scrutinised and, if it involved dispossession of displaced or otherwise vulnerable people, be rolled back. In practice, however, there might be a certain grey area between well-intended (seeking livelihood security) and ill-intended (predatory accumulation) war-time land transfers. Developing a moral compass and operationalising it is not an easy process, but it is a necessary one if we want to make land governance work for these complex problems.

\section{Conclusions: Ways Forward}

Navigating the complexities involved in land issues related to war-related displacement is not easy. Governments, local societies, and international agencies inevitably need to search for custom-made strategies, as there is no toolkit ready for application in such thoroughly complex settings. There is a need for out-of-the-box solutions tailored to specific local settings that are robust enough to afford a certain degree of security now, while also open enough to move along with a changing society. Starting points for such solutions are a commitment to social justice and a sensitivity to the multiplicity of local concerns, and the realisation that technical solutions need to be connected to a strong moral compass. These elements are not a safeguard against mistakes, but might help to avoid the biggest mistakes and allow for 'good enough' solutions.

Land governance in conflict-affected settings should not aim for closure too soon. Short cuts in the name of stability may backfire. We suggest that viable arrangements are those that move along with the new normalities that develop. The traps of a technofix and a legalistic 'fetish' with land rights should be avoided. Technical measures (such as land registration and certification) can support, but not replace, moral choices. Intervening organizations need to consider what their starting point should be for promoting 'just' solutions to land disputes: existing legal frameworks or local understandings of 
how justice may be done in particular cases? Here, the added value might be located in facilitating local debates about what is 'just' and 'fair,' building on both the legal and the locally legitimate, rather than defining a priori answers.

Land-related interventions in settings of displacement need to give particular attention to how local land disputes represent and feed into wider contestations over power and authority, citizenship, and belonging. Any intervention in land governance affects local debates over who is in charge of what, and who has the legitimacy to make certain claims, and impacts the relations between local citizens and the state. Land governance cannot avoid political choices, as politics are about discussing what is fair and what futures might be built.

Land governance may become part of a gradual process of post-conflict institution building, which is inclusive and responsive. The process itself offers opportunities. Jon Unruh has suggested [26] that building up a system for land governance may be done in an iterative way, taking along multiple stakeholders, drawing on legal pluralism while contributing to state building. Done this way, and taking no short cuts, land governance is more than an instrument to regulate land access; it is about reconstructing society itself.

Author Contributions: This work has been jointly prepared and written by the two authors. Conceptualization: G.v.d.H. and M.v.L.; Investigation: M.v.L. and G.v.d.H.; Writing-Original Draft Preparation, G.v.d.H. and M.v.L.; Writing-Review \& Editing, G.v.d.H. and M.v.L.; Project Administration, M.v.L.; Funding Acquisition: M.v.L. and G.v.d.H.

Funding: This paper builds on research that took place within the projects 'Grounding Land Governance' (funded by NWO Wotro Science for Global Development, project number W 01.65.332.00, 2011-2016); 'Land governance as an avenue for local state building in eastern DRC' (co-financed by the IS Academy Human Security in Fragile States, hosted by the Special Chair on Humanitarian Aid and Reconstruction at Wageningen University, 2012); 'Looking through the Lens of Land' (funded by the Security \& Rule of Law in Fragile and Conflict-Affected Settings research programme, under the Applied Research Fund: Embedding Justice in Power and Politics, grant number W 08.400.104, 2014-2016).

Acknowledgments: We owe much to the discussions with colleagues and participants in the research projects mentioned and their willingness to share their views and concerns. We also wish to thank the anonymous reviewers for their comments on earlier versions of this paper. Any mistakes are ours.

Conflicts of Interest: The authors declare no conflict of interest.

\section{References}

1. UNHCR Statistical Yearbooks. Available online: https://www.unhcr.org/figures-at-a-glance.html (accessed on 15 April 2019).

2. Palmer, D.; Szilard, F.; Wehrmann, B. Towards Improved Land Governance; Land Tenure Working Paper 11; FAO, UN-Habitat: Rome, Italy, 2009.

3. Kamungi, P.M.; Oketch, J.S.; Huggins, C. Land Access and Refugee Repatriation; The Case of Burundi; Eco-conflicts, 3(2); African Centre for Technology Studies: Nairobi, Kenya, 2004.

4. Gatunange, G. La problématique foncière dans la perspective du rapatriement et de la réinsertion des sinistres; Rapport provisoire; Observatoire de l'Action Gouvernementale: Bujumbura, Burundi, 2004.

5. Anseeuw, W.; Alden, C. (Eds.) The Struggle over Land in Africa; Conflicts, Politics \& Change; Human Sciences Research Council: Cape Town, South Africa, 2010.

6. Huggins, C.; Clover, J. (Eds.) From the Ground up: Land Rights, Conflict and Peace in Sub-Saharan Africa; Institute for Security Studies: Pretoria, South Africa, 2005.

7. De Wit, P. Land Property Study in Sudan; Interim Report: Scoping of Issues and Questions to Be Addressed; Unpublished; Norwegian Refugee Council, UNHCR, FAO: Rome, Italy, 2004.

8. Pantuliano, S. The Land Question: Sudan's Peace Nemesis; Humanitarian Policy Group (HPG): London, UK, 2007.

9. McCallin, B.; Montemurro, M. Whose Land Is This? Land Disputes and Forced Displacement in the Western Forest Area of Côte d'Ivoire; Internal Displacement Monitoring Centre: Geneva, Switzerland, 2009.

10. Grajales, J. The rifle and the title: Paramilitary violence, land grab and land control in Colombia. J. Peasant Stud. 2011, 38, 771-792. [CrossRef] 
11. Woods, K. Ceasefire capitalism: Military-private partnerships, resource concessions and military-state building in the Burma-China borderlands. J. Peasant Stud. 2011, 38, 747-770. [CrossRef]

12. Oketch, J.S.; Polzer, T. Conflict and coffee in Burundi. In Scarcity and Surfeit: The Ecology of Africa's Conflicts; Lind, J., Sturman, K., Eds.; ACTS Press, Institute for Security Studies: Pretoria, Nairobi, 2002.

13. Mabikke, S. Escalating land grabbing in post-conflict regions of Northern Uganda: A need for strengthening good land governance in Acholi Region. Paper presented at the International Conference on Global Land Grabbing, Brighton, UK, 6-8 April 2011; Institute of Development Studies, University of Sussex: Brighton, UK, 2011.

14. ICG. The Kivus: The Forgotten Crucible of the Congo Conflict; Africa Report $N^{\circ} 56$; International Crisis Group (ICG): Nairobi, Brussels, 2003.

15. Myers, G.W. Competitive rights, competitive claims: Land access in post-war Mozambique. J. South. Afr. Stud. 1994, 20, 603-632. [CrossRef]

16. Pantuliano, S. (Ed.) Charting the way: Integrating land issues in humanitarian action. In Uncharted Territory; Land, Conflict and Humanitarian Action; Practical Action Publishing Ltd.: Warwickshire, UK, 2009.

17. CARE, APDH, Global Rights. Enquête Qualitative sur la Situation des Conflits Fonciers dans la Province de Ngozi Burundi; CARE International au Burundi, APDH, Global Rights: Ngozi, Burundi, 2004.

18. Tchatchoua-Djomo, R.; van der Haar, G.; Van Dijk, H.; Van Leeuwen, M. Intricate links; Displacement, ethno-political conflict, and claim-making to land in Burundi. Geoforum 2018, in press, online version available. [CrossRef]

19. Alden Wily, L. 'The Law is to Blame': The vulnerable status of common property rights in Sub-Saharan Africa. Dev. Chang. 2011, 42, 733-757. [CrossRef]

20. Van Overbeek, F.; Tamas, P. Claim-making through subjectivation: A governmentality analysis of associational performance to claim land in the hybridity of peri-urban Bukavu. Geoforum 2018, in press, online version available. [CrossRef]

21. Büscher, K.; Cuvelier, J.; Mushobekwa, F. La dimension politique de l'urbanisation minière dans un contexte fragile de conflit armé: Le cas de Nyabibwe. In L'Afrique des Grands Lacs: Annuaire 2013-2014; Verpoorten, M., Vandeginste, S., Reyntjens, F., Eds.; l'Harmattan: Paris, France, 2014; pp. 243-268.

22. Justin, P.H.; van Leeuwen, M. The politics of displacement-related land conflict in Yei River County, South Sudan. J. Mod. Afr. Stud. 2016, 54, 419-442. [CrossRef]

23. Sluga, N. Still a Long Way to Go: Local Integration of IDPs in Yei, Southern Sudan; Paper presented during expert seminar on protracted internal displacement; Internal Displacement Monitoring Centre (IDMC) of the Norwegian Refugees Council (NRC): Geneva, Switzerland, 2010.

24. Jacobsen, K. Refugees and asylum seekers in urban areas: A livelihoods perspective. J. Refugee Stud. 2006, 19, 273-286. [CrossRef]

25. Pavanello, S.; Elhawary, S.; Pantuliano, S. Hidden and Exposed: Urban Refugees in Nairobi, Kenya; HPG Working Paper; ODI: London, UK, 2010.

26. De Bruijne, M. Negotiating Borders of Exception; Humanitarian Spill-Overs and Refugee Hosting Communities in Kasulu Distrinct, North-Western Tanzania. Unpublished MSc. Thesis, Wageningen University, Wageningen, The Netherlands, 2018.

27. Unruh, J.D. Land tenure and legal pluralism in the peace process. Peace Chang. 2003, 20, 352-377. [CrossRef]

28. Korf, B.; Funfgeld, H. War and the commons; Assessing the changing politics of violence, access and entitlements in Sri Lanka. Geoforum 2006, 37, 391-403. [CrossRef]

29. Deslaurier, C. Le 'Bushingantahe'; Peut-il réconcilier le Burundi? Polit. Afr. 2003, 92, 76-96. [CrossRef]

30. Vircoulon, T. The Ituri paradox; When armed groups have a land policy and peacemakers do not. In The Struggle Over Land in Africa; Conflicts, Politics and Change; Anseeuw, W., Alden, C., Eds.; HSRC Press: Cape Town, South Africa, 2010.

31. Van der Haar, G. Land reform, the state and the Zapatista uprising in Chiapas. J. Peasant Stud. 2005, 32, 484-507. [CrossRef]

32. Justin, P.H.; van Dijk, H. Land reform and conflict in South Sudan: Evidence from Yei River County. Afr. Spectr. 2017, 52, 3-28. [CrossRef]

33. Van Leeuwen, M.; van de Kerkhof, M.; van Leynseele, Y. Transforming land governance and strengthening the state in South Sudan. Afr. Aff. 2018, 117, 286-309. [CrossRef] 
34. Kobusingye, D.N. African youths; The forgotten category in land governance; A Case study of Post-conflict Acholi Sub-Region, Northern Uganda. Geoforum 2018, in press, online version available. [CrossRef]

35. Whyte, S.R.; Acio, E. Generations and access to land in post-conflict Northern Uganda; "Youth have no voice in land matters". Afr. Stud. Rev. 2017, 60, 17-36. [CrossRef]

36. Alden Wily, L. Tackling land tenure in the emergency to development transition in post-conflict states; From restitution to reform. In Uncharted Territory; Land, Conflict and Humanitarian Action; Pantuliano, S., Ed.; Practical Action Publishing Ltd.: Warwickshire, UK, 2009.

37. Van Leeuwen, M.; van der Haar, G. Land Governance as an Avenue for Local State Building in Eastern DRC; Occasional Paper 07; IS Academy on Human Security in Fragile States: Wageningen, The Netherlands, 2014.

38. Badiey, N. The strategic instrumentalization of land tenure in 'state-building': The case of Juba, South Sudan. Africa 2013, 83, 57-77. [CrossRef]

39. Leonardi, C. Paying "buckets of blood" for the land: Moral debates over economy, war and state in Southern Sudan. J. Mod. Afr. Stud. 2011, 49, 215-240. [CrossRef]

40. Van der Haar, G.; van Leeuwen, M. Post Conflict 'Land Grabbing'; Governance Challenges. In Proceedings of the World Bank Conference Land and Poverty 2013, Washington, DC, USA, 8-11 April 2013.

41. Paris, R. At War's End: Building Peace after Civil Conflict; Cambridge University Press: Cambridge, UK, 2004.

42. Pugh, M.; Cooper, N.; Turner, M. (Eds.) Whose Peace? Critical Perspectives on the Political Economy of Peacebuilding; Palgrave MacMillan: Basingtoke, UK, 2008.

43. Collier, P.; Elliott, V.L.; Hegre, H.; Hoeffler, A.; Reynal-Querol, M.; Sambanis, N. Breaking the Conflict Trap; Civil War and Development Policy; World Bank, Oxford University Press: Washington, DC, USA, 2003.

44. Van Leeuwen, M.; Mathys, G.; De Vries, L.; Van der Haar, G. From peacebuilding to agrarian change; Mediating a dispute of displaced plantation workers in conflict-affected eastern DR Congo. Unpublished work. 2019.

45. Pottier, J. Land reform for peace? Rwanda's 2005 land law in context. J. Agrar. Chang. 2006, 6, 509-537. [CrossRef]

46. Ansoms, A. Striving for growth, bypassing the poor? A critical review of Rwanda's rural sector policies. J. Mod. Afr. Stud. 2008, 46,1-32. [CrossRef]

47. Richards, P. To fight or to farm? Agrarian dimensions of the Mano river conflict (Liberia and Sierra Leone). Afr. Aff. 2005, 104, 571-590. [CrossRef]

48. Van Leeuwen, M. Crisis or continuity? Framing land disputes and local conflict resolution in Burundi. Land Use Policy 2010, 27, 753-762. [CrossRef]

49. Deininger, K. Land Policies for Growth and Poverty Reduction; A World Bank Policy Research Report; Oxford University Press: Oxford, UK, 2003.

50. Peters, P.E. Challenges in land tenure and land reform in Africa: Anthropological contributions. World Dev. 2009, 37, 1317-1325. [CrossRef]

51. Suhrke, A.; Wimpelmann, T.; Dawes, M. Peace Processes and Statebuilding: Economic and Institutional Provisions of Peace Agreements; Chr. Michelsen Institut: Bergen, Norway, 2008.

52. Lund, C.; Boone, C. Introduction: Land politics in Africa; Constituting authority over territory, property and persons. Africa 2013, 83, 1-13. [CrossRef]

53. Kobusingye, D.N. Land in Post-Conflict Situations: War, Decentralization, Land Governance and State Formation in Northern Uganda. Unpublished Ph.D. Thesis, Wageningen University, Wageningen, The Netherlands, 2018.

54. LEMU. What Happens if I Get a Certificate of Customary Ownership? Land and Equity Movement of Uganda: Kampala, Uganda, 2008; Available online: http://www.land-in-uganda.org/assets/What\%20happens\%202.pdf (accessed on 18 January 2019).

55. Meynen, W.; Doornbos, M. Decentralising natural resource management: A recipe for sustainability and equity? Eur. J. Dev. Res. 2004, 16, 235-254. [CrossRef]

56. Peters, P.E. Inequality and social conflict over land in Africa. J. Agrar. Chang. 2004, 4, 269-314. [CrossRef]

57. Nyenyezi Bisoka, A.; Ansoms, A. Arène foncière au Burundi: Mieux comprendre les rapports de force. In L'Afrique des grands lacs; Annuaire 2011-2012; Reyntjens, F., Vandeginste, S., Verpoorten, M., Eds.; L'Harmattan: Paris, France, 2012.

58. Leegwater, M. Sharing Scarcity: Land Access and Social Relations in Southeast Rwanda; African Studies Collection Issue 60; African Studies Centre: Leiden, The Netherlands, 2015. 
59. Black, R. Conceptions of 'home' and the political geography of refugee repatriation; Between assumption and contested reality in Bosnia-Herzegovina. Appl. Geogr. 2002, 22, 123-138. [CrossRef]

60. Mathys, G.; Büscher, K. Urbanizing Kitchanga: Spatial trajectories of the politics of refuge in North Kivu, Eastern Congo. J. East. Afr. Stud. 2018, 12, 232-253. [CrossRef]

(C) 2019 by the authors. Licensee MDPI, Basel, Switzerland. This article is an open access article distributed under the terms and conditions of the Creative Commons Attribution (CC BY) license (http://creativecommons.org/licenses/by/4.0/). 